\title{
Effect on Monetary Return in Various Pruning Intensities and Agronomical Management on Dalbergia sissoo Biomass Production under Agrisilviculture System
}

\author{
Ragni Bhargava* and Nikita Rai
}

Tropical Forest Research Institute, Jabalpur (M. P.), India

*Corresponding author

\section{Keywords}

Agronomical

Management, Pruning intensities, Monetary return \& Agrisilviculture system

Article Info

Accepted:

18 May 2019

Available Online:

10 June 2019

\section{A B S T R A C T}

The experiment was carried out at dusty acre farm, Department of Forestry, College of Agriculture, J.N.K.V.V. Jabalpur during the year 2014- 2015. Manipulation in agronomical practice like higher seed rate, fertilizer dose with different pruning intensities which can compensate the yield reduction to shade under agrisilviculture system. The experiment consists of four pruning intensities viz., no pruning, 25\% pruning, 50\% pruning and $75 \%$ pruning and one open condition (no tree crop only) in main plot and three levels of fertilizer doses and seed rate viz., $\mathrm{T}_{1}$ recommended dose of fertilizer and seed rate, $\mathrm{T}_{2}$ $\mathrm{T}_{1+} 25 \%$ more nitrogen than recommended dose of fertilizer and $\mathrm{T}_{3}-\mathrm{T}_{1}+25 \%$ more seed rate than recommended dose of seed rate in sub plot replication in 5 times. $75 \%$ pruning recorded significantly higher yield attributing characters as compared no pruning. Different pruning treatment showed significant effect on net monetary return. 25\% pruning recorded significantly higher monetary return (Rs 2,47,566.3 ha ${ }^{-1}$ ) at par with $50 \%$ pruning (Rs $218854.5 \mathrm{ha}^{-1}$ ) but significantly superior to $75 \%$ pruning (Rs $1,25,151.9 \mathrm{ha}^{-1}$ ). Under managed agroforestry system i.e. D. sissoo in $25 \%$ pruning recorded higher monetary return (Rs 2,47,566.3 ha- ${ }^{-1}$ ) then tree alone (Rs 2,01,217.425 ha- ${ }^{-1}$ ) and unmanaged agroforestry system i.e. no pruning (Rs $2,11,111.4 \mathrm{ha}^{-1}$ ). Agronomical management $\mathrm{T}_{2}$ i.e. $25 \%$ more nitrogen than recomended dose gave significantly higher monetary return (Rs 2,05,650.7 ha ${ }^{-1}$ ) and compare to recommended dose of nitrogen and seed rate i.e $\mathrm{T}_{1}$ (Rs $1,97,791 \mathrm{ha}^{-1}$ ) but at par with $\mathrm{T}_{3}$. The maximum biomass percent increased by $25 \%$ pruning, no pruning, $50 \%$ pruning as compare to $75 \%$ pruning.

\section{Introduction}

Agroforestry is one of the best options to increase the tree cover outside the forest area. Growing of fast growing trees in association with arable crops will not only improve the sustainability of farming systems, but also diversify farmer's income, provide new products to the wood based industry, meet increasing energy requirements, generate employment and create novel landscapes of high value for the generations in posterity.

Shisham is classical example of a pioneer species in the riverian succession of the Gangetic alluvium in India. The species 
occurs naturally on sandy and gravelly alluvial ground along the banks of rivers and stream. There is remarkable variation in growth pattern and the yield per unit area due to the wide adaptability of the tree in different ecological sites. The leaf fall begins in November-December and also depending upon the climatic conditions. The mean temperature and humidity play an important role than rainfall in controlling leafing and flowering.

In Madhya Pradesh, as traditional agroforestry system, tree legumes (e.g. Acacia nilotica, Butea monosperma and Dalbergia sissoo) were found growing respectively for fuel, fodder and small timber purpose in both extensive grazing system and in association with field crop (Fujimori and Waseda, 1972).

The most suitable trees for agroforestry system are those having less spread canopy, fast growing in nature, clean bole, nitrogen fixing capacity and protein rich fodder. Dalbergia sissoo Roxb. (Shisham), is one of them a moderately fast growing and nitrogen fixing tree has an advantage to include in agroforestry system.

\section{Materials and Method}

\section{Experimental field}

The field experiment was conducted at New Dusty Acres Area Research Farm, Department of Forestry, Jawaharlal Nehru Krishi Vishwa Vidyalaya, Jabalpur during Rabi season of 2014-15.

\section{Climatic and soil condition}

The climate of the region is semi arid and area receives an average rainfall of about 1350 $\mathrm{mm}$. annually. The mean monthly minimum temperature varies between 5.3 to $6.1^{\circ} \mathrm{C}$ in December and January, and maximum temperature varies between 40 to $42^{\circ} \mathrm{C}$ during May and June, respectively. The soil of the experiment site was clay loam in nature with medium in available Nitrogen $\left(288.1 \mathrm{~kg} \mathrm{ha}^{-1}\right)$, high in texture Phosphorus $\left(8 \mathrm{~kg} \mathrm{ha}^{-1}\right)$ and very low in texture $\mathrm{K}\left(1170.45 \mathrm{~kg} \mathrm{ha}^{-1}\right)$. The soil was acidic in nature with $5.93 \mathrm{pH}$.

\section{Recorded Observation}

The tree growth parameters such as Height(m), Diameter at breast height (cm.), Pruned biomass $\left(\mathrm{Kg} \mathrm{ha}^{-1}\right)$, Crown spread $(\mathrm{N}-$ $\mathrm{S}, \mathrm{E}-\mathrm{W})$, Cylindrical volume of the tree $\left(\mathrm{m}^{3}\right.$ $\left.\mathrm{ha}^{-1}\right)$ and Stand biomass $\left(\mathrm{Kg} \mathrm{ha}{ }^{-1}\right)$ were recorded to know the effect of various pruning intensities and agronomical management on D. sissoo biomass production under agrisilviculture.

\section{Height}

The height of individual tree in each block was measured from the ground level to the tip of the main stem with the help of a measuring tape. It is expressed in meter.

\section{Diameter at breast height $(\mathrm{dbh}$ in $\mathrm{cm})$}

Diameter at breast height (dbh) of individual tree of each block was measured with the help of diameter tape at $1.37 \mathrm{~m}$ above ground level. It is expressed in $\mathrm{cm}$.

\section{Pruned biomass $\left(\mathrm{Kg} \mathrm{ha}^{-1}\right)$}

Trees were pruned (cutting of branches) as per treatment. Pruned materials were weighed accurately to calculate pruned biomass per ha by multiplying with factor i.e. 400 (400 plants/ha).

\section{Cylindrical volume of the tree $\left(\mathrm{m}^{3} \mathrm{ha}^{-1}\right)$}

It was estimated by using quarter girth formula i.e. $\log$ volume $=(\mathrm{g} / 4)^{2} \mathrm{X} \mathrm{L}$ 
Volume $=$ Basel diameter $\times$ height of tree

\section{Stand biomass of trees $\left(\mathrm{Kg} \mathrm{ha}^{-1}\right)$}

Stand biomass of trees was estimated by using formula i.e. Weight $=$ Volume of tree $\mathrm{x}$ specific gravity of tree $(0.77)$

\section{Canopy spread (N-S, E-W)}

Canopy spread of the trees was measured with the help of measuring tape.

First of all East-West direction was marked with a wooden stick at last shoot tip of each direction.

The distance between North-South and EastWest shoot tip was measured as crown length with measuring tape.

\section{Results and Discussion}

All the morphological characters (except tree height) were significantly affected by pruning treatment. 25\% pruning recorded significantly higher dbh (23.98), cylindrical volume $\left(217.27 \mathrm{~m}^{3} \mathrm{ha}^{-1}\right)$ and stand biomass $(1,67,301$ $\mathrm{Kg} \mathrm{ha}^{-1}$ ) as compared to $75 \%$ pruning (Table $1)$.

Canopy spread in both N-S and E-W direction was maximum in no pruning $(7.83 \& 7.24)$ whereas lowest in $75 \%$ pruning ( $3.95 \& 4.11$ ).

Significantly highest cylindrical volume and stand biomass was recorded in $25 \%$ pruning intensities and lowest in 75\% pruning (100.87 $\mathrm{m}^{3} \mathrm{ha}^{-1} \& 77,671 \mathrm{Kg} \mathrm{ha}^{-1}$ ) (Muhairwe, 1994).

\section{Net monetary return (Rs/ha/year)}

Different pruning treatment showed significant effect on net monetary return. 25\% pruning recorded significantly higher monetary return (Rs 2,47,566.3 ha ${ }^{-1}$ ) at par with $50 \%$ pruning (Rs 2,18,854.5 $\mathrm{ha}^{-1}$ ) but significantly superior to $75 \%$ pruning (Rs 1,25,151.9 $\mathrm{ha}^{-1}$ ). Under managed agroforestry system i.e. D. sissoo in $25 \%$ pruning recorded higher monetary return (Rs 2,47,566.3 ha ${ }^{-1}$ ) then tree alone (Rs 201217.425 $\mathrm{ha}^{-1}$ ) and unmanaged agroforestry system i.e. no pruning (Rs 2,11,111.4 ha ${ }^{-1}$ ).

Pruning treatment showed no significant effect on tree height. A similar result was also reported by (Couto and Gomes, 1995), 25\% pruning recorded highest $\mathrm{dbh}(23.98 \mathrm{~cm})$

(Bredenkamp et al., 1980; Pinkard and Beedle, 1998; Pires et al., 2002; Pinkard et al., 2004), N-S (5.93) and E-W (6.08), cylindrical volume $\left(217.27 \mathrm{~m}^{3} \mathrm{ha}^{-1}\right)$ and stand biomass $\left(167301 \mathrm{~kg} \mathrm{ha}^{-1}\right)$ but at par with no pruning, $50 \%$ but significantly superior to $75 \%$ pruning (Bhargava., 2003).

D. sissoo in $25 \%$ pruning recorded significantly higher monetary return (Rs $2,47,566.3 \mathrm{ha}^{-1}$ ) at par with $50 \%$ pruning (Rs $\left.2,18,854.5 \mathrm{ha}^{-1}\right)$ but significantly superior to no pruning (Rs 2,11,111.4 ha ${ }^{-1}$ ), $75 \%$ pruning (Rs 1,25,151.9 ha ${ }^{-1}$ ), and tree alone (Rs $\left.40,243.5 \mathrm{ha}^{-1}\right)$.

Different pruning treatment showed significant effect on net monetary return (Koshta et al., 2011) (Table 2).

\section{Suggestions for further work}

The economics should be workout for large period with different timber tree in different climatic and edaphic condition.

Experiment should be carried out with some important MPTS tree species like Siris, Babul, Khamer, which is also important species of Madhya Pradesh.

Carbon sequestration, carbon storage, carbon budgeting etc studies should be carried out. 
Table.1 Morphological growth characters and biomass of $D$. sissoo as influenced by different pruning intensities and agronomical management under agrisilviculture system at the age of 16 years

\begin{tabular}{|c|c|c|c|c|c|c|c|}
\hline \multirow[t]{2}{*}{ Treatment } & \multirow{2}{*}{$\begin{array}{l}\text { Tree } \\
\text { Height } \\
\quad(\mathbf{m})\end{array}$} & \multirow{2}{*}{$\begin{array}{l}\text { dbh- } \\
1.37 \\
(\mathrm{~cm})\end{array}$} & \multicolumn{2}{|c|}{$\begin{array}{c}\text { Canopy } \\
\text { spread }(m)\end{array}$} & \multirow{2}{*}{$\begin{array}{c}\text { Pruned } \\
\text { biomass } \\
\left(\mathrm{Kg} \mathrm{ha}^{-1}\right)\end{array}$} & \multirow{2}{*}{$\begin{array}{c}\text { Cylindrical } \\
\text { Volume } \\
\left(\mathrm{m}^{3} \mathrm{ha}^{-1}\right)\end{array}$} & \multirow{2}{*}{$\begin{array}{c}\text { Stand } \\
\text { biomass } \\
\left(\mathrm{Kgha}^{-1}\right)\end{array}$} \\
\hline & & & $\mathrm{N}-\mathrm{S}$ & $\mathbf{E}-\mathbf{W}$ & & & \\
\hline \multicolumn{8}{|c|}{ Pruning Intensities } \\
\hline$P_{0}-$ No pruning & 10.56 & 24.05 & 7.83 & 7.24 & - & 192.55 & $1,48,262$ \\
\hline $\begin{array}{l}P_{1}- \\
\text { pruning }\end{array}$ & 11.92 & 23.98 & 5.93 & 6.08 & 1668 & 217.27 & $1,67,301$ \\
\hline $\begin{array}{ll}\mathbf{P}_{2} & - \\
\text { pruning } & \mathbf{5 0 \%}\end{array}$ & 11.31 & 22.71 & 5.21 & 5.05 & 1864 & 187.22 & $1,44,160$ \\
\hline $\begin{array}{l}\mathrm{P}_{3}- \\
\text { pruning }\end{array}$ & 10.06 & 17.28 & 3.95 & 4.11 & 2010 & 100.87 & 77,671 \\
\hline SEm \pm & 0.59 & 1.67 & 0.81 & 0.64 & 141.2 & 26.78 & 20,619 \\
\hline CD $(P=0.05)$ & NS & 5.34 & 2.61 & 2.06 & NS & 85.65 & 65,949 \\
\hline \multicolumn{8}{|c|}{ Agronomical Management } \\
\hline $\begin{array}{l}\text { T1- } \\
\text { [Recommended } \\
\text { dose of SR and } \\
\text { FD (control)] }\end{array}$ & 10.9 & 22.2 & 6.1 & 6.3 & 1422 & 177.7 & $1,36,864$ \\
\hline $\begin{array}{l}\mathrm{T} 2-[\mathrm{T} 1+25 \% \\
\text { more nitrogen } \\
\text { than } \\
\text { recommended } \\
\text { dose] }\end{array}$ & 11.0 & 22.0 & 5.5 & 5.2 & 1386 & 172.0 & $1,32,410$ \\
\hline $\begin{array}{l}\text { T3- }[\mathrm{T} 1+25 \% \\
\text { more seed rate } \\
\text { than } \\
\text { recommended } \\
\text { dose] }\end{array}$ & 11.0 & 21.8 & 5.6 & 5.7 & 1450 & 171.3 & $\mathbf{1 , 3 1 , 8 8 5}$ \\
\hline $\begin{array}{l}\text { Tree only- no } \\
\text { crop }\end{array}$ & 11.0 & 22.0 & 5.8 & 5.3 & 1284 & 176. & $1,36,235$ \\
\hline $\operatorname{SEm} \pm$ & 0.18 & 0.63 & 0.88 & 1.03 & 95 & 8.85 & 6,818 \\
\hline CD $(P=0.05)$ & NS & NS & NS & NS & NS & NS & NS \\
\hline
\end{tabular}


Table.2 Net monetary return (Rs. ha $\left.{ }^{-1}\right)$ as influence by different pruning intensities in D.sissoo

\begin{tabular}{|c|c|c|c|c|c|c|}
\hline $\begin{array}{l}\text { Agronomical } \\
\text { Management } \\
\text { Pruning } \\
\text { Intensities }\end{array}$ & $\begin{array}{c}\text { T1 } \\
\text { [Recommended } \\
\text { dose of seed rate } \\
\text { and fertilizer] }\end{array}$ & $\begin{array}{c}\mathrm{T} 2 \\
{[\mathrm{~T} 1+25 \%} \\
\text { more nitrogen } \\
\text { than } \\
\text { recommended } \\
\text { dose }]\end{array}$ & $\begin{array}{c}\mathrm{T} 3 \\
{[\mathrm{~T} 1+25 \%} \\
\text { more seed rate } \\
\text { than } \\
\text { recommended] }\end{array}$ & Mean & Grand Mean & Tree alone \\
\hline$P_{0}-$ No pruning & $2,25,361.9$ & $1,88,325.4$ & $2,19,647.1$ & $2,11,111.4$ & & $1,93,303.9$ \\
\hline$P_{1}-25 \%$ pruning & $2,44,344.0$ & $2,69,279.5$ & $2,29,075.4$ & $2,47,566.3$ & \multirow[b]{3}{*}{$4,66,413.1$} & $2,69,734.3$ \\
\hline$P_{2^{-}} \mathbf{5 0 \%}$ pruning & $1,95,560.8$ & $2,41,872.7$ & $2,19,130.2$ & $2,18,854.5$ & & $2,30,839.8$ \\
\hline$P_{3}-75 \%$ pruning & $1,25,897.6$ & $1,23,125.5$ & $1,26,432.6$ & $1,25,151.9$ & & $1,10,991.7$ \\
\hline Mean & 197791 & 205650.7 & 198571.3 & 402587.6 & & 201217.4 \\
\hline $\begin{array}{l}\text { Pruning inten } \\
\text { Agronomical }\end{array}$ & $\begin{array}{l}\text { nsities } \\
\text { management }\end{array}$ & & $\begin{array}{l}\text { Em } \pm \\
973 \\
299\end{array}$ & $\begin{array}{l}\text { CD (P } \\
19105 \\
7353\end{array}$ & $.05)$ & \\
\hline
\end{tabular}

\section{Acknowledgement}

Authors are thankful to Head, Department of Forestry, Jawaharlal Nehru Krishi Vishwa Vidhyalaya. Jabalpur. Authors are also great full for Major guide, Dr. L.D. Kostha, Professor (CAS), and Minor Guide, Dr. K. K. Jain, Professor (CAS), and Dr. H. L. Sharma, Professor, and Head, Department of mathematics and Agriculture Statistics for constant support and guidance during the research work.

\section{References}

Bhargava, M. K., (2003) Studies on Tree Crop Interaction In Albizia Procera Based Agroforestry System In Relation To Soil Moisture, Light and Nutrients. Ph.D. Thesis (Agronomy), Faculty of Agriculture Science, Bundelkhand University, Jhansi.

Bredenkamp, B. V., Malan, F.S. and Conradie, W.E. (1980) Some effects of pruning on growth and timber quality of Eucalyptus grandis in Zuzuland. South African Forestry Journal, 114: 29-34.

Couto, L. and Gomes, J.M. (1995)
Intercropping Eucalyptus with beans in Minas Gerais, Brazil. International Tree Crop Journal, 8: 83-93.

Fujimori, E. and Waseda, O. (1972) Fundamentals studies on pruning II. Effects of pruning on stem growth (I). Bulletin of the Government Experimental Station, 244:1-15.

Koshta, L.D., Upadhyaya, S.D., Jain, K.K. and Nayak, H. (2011) Pruning Management in Guava for Higher yield of Fruit and Kharif crops under Agrihorticulture Practice of Agroforestry. Indian Forest Congress, pp 65-66.

Pinkard, E. A. and Beadle, C.L. (1998) Regulation of photosynthesis in Eucalyptus nitens (Deane and Maiden) Maiden following pruning. Trees, 12: 366-376.

Pinkard, E. A., Mohammed, C.L., Hall, M. F., Worledge, D. and Nollon, A. (2004) Growth responses, physiology and decay associated with pruning plantation-grown Eucalyptus globulus Labill and $E$. nitens (Deane and Maiden) Maiden. Forest Ecology and Management, 200: 263-270. 
Pires, B.M., Reis, M.G.F. and Reis, G.G-das., Eucalyptus grandis on Southeastern (2002) Pruning effect on growth of Brazil. Brazil Florestal, 21: 13-21.

\section{How to cite this article:}

Ragni Bhargava and Nikita Rai. 2019. Effect on Monetary Return in Various Pruning Intensities and Agronomical Management on Dalbergia sissoo Biomass Production under Agrisilviculture System. Int.J.Curr.Microbiol.App.Sci. 8(06): 2444-2449. doi: https://doi.org/10.20546/ijcmas.2019.806.291 